\title{
GERAKAN DAKWAH AKTIVIS PEREMPUAN 'AISYIYAH JAWA TENGAH
}

\author{
Dedy Susanto \\ Fakultas Dakwah dan Komunikasi \\ IAIN Walisongo Semarang
}

\begin{abstract}
Abstrak
Gerakan dakwah diartikan setiap aktivitas dalam rangka melaksanakan dakwah Islam untuk mengajak manusia kepada kebaikan, menyuruh kepada yang ma'ruf dan mencegah dari yang munkar, adapun secara khusus, gerakan dakwah sering disebut sebagai gerakan Islam (al-harakah al-Islamiyah) atau juga disebut jamaah dakwah atau juga disebut kutlah da'wah (kelompok dakwah), yaitu sebuah kelompok yang terdiri dari orang-orang yang bersama-sama melaksanakan dakwah dalam satu kesatuan kerja dan koordinasi. Gerakan dakwah para aktivis perempuan 'Aisyiyah Jawa Tengah sudah dilakukan dengan penggerakan organisasi yang ideal, hal ini dapat dilihat dari berbagai koordinasi dan kerja sama antar lembaga dalam organisasi. Solidnya kerjasama yang dilakukan menjadikan 'Aisyiyah dapat mengaplikasikan kegiatan dakwahnya di masyarakat. Kegiatan dakwah yang dilakukannya secara langsung dapat berdampak positif bagi anggota dan masyarakat luas dari berbagai bidang kehidupan.
\end{abstract}

Kata Kunci: gerakan dakwah, Aisyiyah, Jawa Tengah

\section{A. Pendahuluan}

Dakwah pada hakekatnya adalah mengaktualisasikan nilai-nilai dan ajaran Islam ke dalam kehidupan sehari-hari, dalam lingkup pribadi, keluarga, dan masyarakat sehingga terwujudnya khairu ummah yang sejahtera lahir batin, bahagia dunia dan akhirat. Dakwah berarti proses penyelenggaraan dakwah baik dilakukan secara individu terlebih lagi secara kelompok melalui organisasi maupun lembaga dengan melalui langkahlangkah, menetapkan sasaran, tujuan, bentuk kegiatan dan langkah-langkah sistematis dalam proses kegiatan, untuk mencapai tujuan dakwah itu sendiri secara optimal, efektif dan efesien. 
Islam merupakan agama dakwah, dimana di dalamnya terdapat usaha menyebarluaskan kebenaran ajaran yang diyakini berasal dari Allah SWT, untuk disebarluaskan kepada semua manusia. Semangat menyebarluaskan kebenaran ini merupakan tugas suci dan wujud pengabdian kepada Tuhan. Melaksanakan dakwah (menegakkan amar ma'rûf nahi munkar) merupakan kewajiban semua umat Islam baik laki-laki maupun perempuan, baik dilakukan secara individu maupun berkelompok yang terorganisir.

Dakwah menjadi tugas setiap muslim dalam pengertian yang sederhana (dalam skala mikro) sesuai dengan kapasitas dan kemampuannya. Namun dalam pengertian dakwah secara ideal dan makro, baik yang dilakukan oleh individu maupun kelompok (organisasi) harus dilakukan dengan menguasai berbagai aspek, baik metode, materi, media, dan menguasai sasaran dakwah, di samping juga pelaksana dakwah harus memiliki integritas, kapabelitas, kredibelitas baik dari segi keahliannya maupun moralitasnya, dan memiliki kepribadian yang shalih untuk menghasilkan pelaksanaan dakwah secara efektif dan efesien, harus dilakukan secara sistemik dengan menerapkan aspek-aspek manajerial secara baik dan tepat.

Dakwah di era modern saat ini harus tanggap terhadap perubahan di dalam masyarakat dari berbagai bidang. Masyarakat menjadi semacam universitas terbuka yang selalu siap menerima berbagai piranti budaya baru dalam skala yang relatif tidak terbatas. Dinamika masyarakat dapat dilihat dari kecenderungan rasionaliasi, teknikalisasi, serta rasionalisasi ekonomi yang melahirkan kalkulasi pada segala relung kehidupan sebagai bagian integral dari modernisasi bangsa. ${ }^{1}$

Kondisi tersebut di atas ditambah dengan perkembangan ilmu pengetahuan dan teknologi yang berjalan sangat cepat menuntut adanya penyelarasan dan penyesuaian media dakwah sebagai salah satu komponen dalam metode dakwah. Ledakan-ledakan informasi dan kemajuan teknologi dalam berbagai bidang itu tidak boleh dibiarkan lewat begitu saja. Namun, harus berusaha mencegah dan mengantisipasi dengan memperkuat

${ }^{1}$ Pramono U. Tantowi, Muhammadiyah "Digugat" Reposisi di Tengah Indonesia yang Berubah, (Jakarta: Kompas Media Nusantara, 2000), hlm. 21. 
benteng pertahanan aqidah yang terpadukan ilmu dan teknologi, sebab jika tidak maka gilirannya akan membuat langkah-langkah dakwah semakin tumpul tidak berdaya. ${ }^{2}$ Oleh karena itu, 'Aisyiyah dituntut untuk dapat menggunakan teknologi tersebut sebagai media penyampaian dakwah, atau meluruskan stigma-stigma tentang Islam yang sudah dibangun oleh para penguasa teknologi yang anti Islam kepada masyarakat yang jangkauannya sangat luas. ${ }^{3}$

Berangkat dari problem di atas, maka beban yang dipikul 'Aisyiyah sangat berat untuk menjalankan fungsi-fungsi sebagai gerakan dakwah kultural, agamis dan reformatif. Ada pertautan timbal balik antara daya dukung yang terbatas, sementara lingkup kegiatan makin luas. Karena itu, persoalan pokok bagi 'Aisyiyah perlu merumuskan strategi barunya. Artinya, eksistensinya di masa depan sangat ditentukan oleh kejelian dalam menangkap semangat zaman, kesadaran organisasinya, kekompakan para pengambil keputusan, kemampuan menjaga jarak dengan birokrasi, ketersediaan sumber daya manusia dalam kuantitas dan kualitas yang seimbang, serta ketepatan dalam memilih program dan kegiatan dalam segenap jajaran organisasi dalam rangka menjalankan aktivitas gerakan dakwahnya.

\section{B. Gerakan Dakwah}

Gerakan berarti perbuatan, kegiatan, aktivitas atau keadaan bergerak. ${ }^{4}$ Kata dakwah secara etimologi berasal dari bahasa Arab da'a, yad'u, da'watan bermakna panggilan, seruan dan ajakan, ${ }^{5}$ sedangkan secara terminologi, kata dakwah seperti yang didefinisikan oleh H.M. Arifin, dakwah berarti menyeru untuk mengikuti sesuatu, dengan cara dan tujuan tertentu, pengertian dakwah

2 Pahlawan Khatib Kayo, Manajemen Dakwah dari Dakwah Konvensional menuju Dakwah Profesional, (Jakarta: Amzah, 2007), hlm. 7.

${ }^{3}$ Safrodin Halimi, Etika Dakwah dalam Perspektif al-Qur'an: Antara Idealitas Qur'ani dan Realitas Sosial, (Semarang: Walisongo Press, 2008), hlm. 38.

${ }^{4}$ Departemen Pendidikan Nasional, Kamus Besar Bahasa Indonesia, (Jakarta: Balai Pustaka, 2005), hlm. 356.

${ }^{5}$ Wafiyah dan Pimay, Sejarah Dakwah, (Semarang: Rasail, 2005), hlm. 3. 
Islam dalam pandangannya adalah menyeru ke jalan Allah yang melibatkan unsur-unsur penyeru, pesan, media, metode dan tujuan. ${ }^{6}$

Secara umum gerakan dakwah diartikan setiap aktivitas dalam rangka melaksanakan dakwah Islam untuk mengajak manusia kepada kebaikan, menyuruh kepada yang ma'ruf dan mencegah dari yang munkar, adapun secara khusus, gerakan dakwah sering disebut sebagai gerakan Islam (alharakah al-islâmiyyah) atau juga disebut jamaah dakwah atau juga disebut kutlah dakwah (kelompok dakwah), yaitu sebuah kelompok yang terdiri dari orang-orang yang bersama-sama melaksanakan dakwah dalam satu kesatuan kerja dan koordinasi.

Harakah ad-da'wah dalam hal ini gerakan dakwah menurut al-Qahthani adalah suatu gerakan yang berorientasikan pada pengembangan masyarakat Islam dengan sistematika mulai dari perbaikan individu (ishlâh al-fard), perbaikan keluarga (ishlâh al-usrah), perbaikan masyarakat (ishlâh almujtama), dan perbaikan pemerintah dan negara (ishlâh al-daulah). ${ }^{7}$

Menurut Mustafa Masyhur, gerakan dakwah mendasarkan diri pada tiga kekuatan sekaligus, yaitu: (1) kekuatan aqidah dan iman, (2) kekuatan persatuan dan ikatan kaum muslimin (quwwat al-wahdah wa al-tarabbuth), (3) dan kekuatan jihad (quwwat al-jihâd). ${ }^{8}$

Menurut Fathi Yakan, ada empat ciri yang sangat menonjol dari gerakan dakwah, yaitu: (1) Murni dan autentik (dzâtiyyah), yakni autentik sebagai panggilan Tuhan, (2) Mendorong kemajuan (taqaddumiyyah), yakni kemajuan yang tetap menjunjung tinggi nilai-nilai moralitas, (3) Universal (syâmilah) mencakup semua aspek kehidupan, memadukan tiga sistem hidup (manhaj al-hayat), yang terdiri dari tiga D; Din (agama), Dunya (dunia) dan Daulah (pemerintahan negara), (4) Menekankan prinsip-prinsip agama yang luhur. ${ }^{9}$

${ }^{6}$ Arifin, Psikologi Dakwah: Suatu Pengantar Studi, (Jakarta: Bumi Aksara, 1993), hlm. 6.

${ }^{7}$ Faizah dan Efendi, Muchsin, Psikologi Dakwah, (Jakarta: Kencana, 2006), hlm. xvi.

8 Ibid.

${ }^{9} \mathrm{Ibid}$. 
Menurut Sayyid Qutub, seorang aktivis dan arsitek gerakan dakwah di Mesir, ada tiga ciri gerakan dakwah, yaitu: (1) Gerakan dakwah lebih menekankan aksi dari pada teori, wacana dan retorika, sebagaimana dakwah Nabi Muhammad SAW yang tidak membangun wacana (lâ yuqim falsafatan) tetapi membangun umat (layubni ummah), (2) Gerakan dakwah membolehkan penggunaan kekuatan fisik dalam bentuk jihad fisabilillah jika keadaan memaksa, (3) Gerakan dakwah sangat meniscayakan organisasi dan jaringan (networking) dalam skala nasional, regional, maupun internasional. Menurut Sayyid Qutub, dakwah bukan hanya tugas individual, tetapi tugas dan kewajiban kolektif seluruh muslim. ${ }^{10}$

Gerakan dakwah menurut Rokhmat merupakan aktivitas yang dilakukan secara bersama-sama atau kolektif yang bertujuan untuk mendorong orang lain atau masyarakat untuk mencapai perubahan yang lebih baik, menurut Rokhmat untuk mengidentifikasi gerakan dakwah tersebut dilihat dari organisasi, lembaga donor, tokoh-tokoh, dan jaringan. ${ }^{11}$

Gerakan dakwah menurut al-Siba'i mempunyai tiga ciri, antara lain: (1) Senantiasa menghidupkan aqidah dan keimanannya sebagai jalan menuju al-Islam, (2) Senantiasa mengarah kepada perbaikan, berjalan seiring dengan kepentingan hidup dan kehidupan manusia, mengikuti perkembangan evolusi berfikir serta kemajuan manusia yang mulia, (3) Mempunyai watak universal (syâmilah), di mana dalam usaha perbaikan, aktivis dakwah tidak hanya terbatas pada satu bidang saja, tetapi meliputi berbagai bidang kehidupan. ${ }^{12}$

Gerakan dakwah Islam menurut Shadiq Amin adalah suatu gerakan yang dilakukan oleh sekelompok orang yang terorganisasi (jama'ah) yang mempunyai beberapa karakteristik, antara lain: (1) Gerakan berlandaskan Kitabullah dan Sunnah Rasulullah SAW dalam menetapkan tujuan, sarana, dan cara menghadapi situasi dan kondisi, (2) Adanya kejelasan visi jama'ah

\footnotetext{
${ }^{10} \mathrm{Ibid} .$, hlm. xvii.

${ }_{11}$ Rokhmat, Abu, Ideologi dan Gerakan Dakwah Salafi Wahabi: Studi Kasus di Kota Semarang, (Semarang: Puslit IAIN Walisongo, 2010), hlm. 125-135.

${ }^{12}$ Fahmi, Abu, Pergilah ke Jalan Islam: Sebuah Paket Gerakan Dakwah Masa Kini, (Jakarta: Gema Insani Press, 1991), hlm. 7.
} 
dan metode dalam mencapai tujuan, (3) Adanya tarbiyah dalam aktivitasnya, (4) Jama'ah dapat memberikan dampak pada sisi amal perbuatan, tidak hanya pada sisi teori dan pemikiran, (5) Mempunyai peraturan bagi jama'ah yang mengikat setiap anggotanya, sehingga tumbuh di dalamnya ukhuwah Islamiyah, loyalitas, keharmonisan dan ketaatan kepada pemimpin, (6) Adanya strategi yang tepat, mempelajari realitas kehidupan secara berkesinambungan terhadap jama'ah. ${ }^{13}$

Ada beberapa karakteristik gerakan dakwah menurut Cecep Yusuf Pramana. Pertama, menjadikan tauhid aqidah sebagai landasannya. Tauhidaqidah merupakan asas Islam, sekaligus inti dari Islam, yaitu sikap pengesaan semurni-murninya, bahwasanya tidak ada Tuhan kecuali Allah, dengan tauhid maka setiap manusia dibebaskan dari penyembahan kepada makhluk, baik yang bersifat materi maupun abstrak, kemudian memusatkan peribadatan kepada Allah semata. Tauhid merupakan inti dakwah yang dibawakan oleh para Nabi dan Rasul, sejak Nabi Adam AS sampai Nabi Muhammad SAW, oleh karena itu gerakan dakwah juga harus menjadikan tauhid sebagai landasannya.

Kedua, melaksanakan aktivitas dakwah. Sebuah gerakan dakwah harus mengemban dakwah, yaitu mengajak kepada kebaikan, menyuruh kepada yang ma'ruf dan mencegah dari yang munkar. Bentuk dakwahnya dapat meliputi dakwah fikriyah (menyebarkan pemahaman Islam), da'wah siyasyah (dakwah melalui strategi politik) dan jika diperlukan maka melakukan da'wah askariyah (dakwah melalui kekuatan militer). Sebuah gerakan dakwah tidak diperkenankan melakukan dakwah sektoral, hanya melakukan dakwah serpihan-serpihan. Gerakan dakwah harus melakukan dan mengajak kepada dakwah Islam yang menyeluruh (kaffah).

Ketiga, bertujuan mengembalikan dan melanjutkan kehidupan Islam. Gerakan dakwah harus bertujuan untuk mengembalikan kehidupan Islam seperti pernah dipraktekkan pada masa Rasulullah SAW dan masa khalifah Islam yaitu diterapkannya hukum-hukum syara' (hukum Islam) dalam ke-

13 Shadiq Amin, Mencari Format Gerakan Dakwah Ideal, (Jakarta: al-I'tishom Cahaya Umat, 2010), hlm. 71-78. 
hidupan. Sekaligus kehidupan tersebut sebagai upaya melanjutkan kehidupan Islam yang pernah dilakukan sebelumnya, dengan demikian umat Islam akan hidup dalam naungan kehidupan Islam. Kehidupan yang penuh kebaikan, sejahtera dan dilimpahi rahmat, barokah dan ampunan dari Allah SWT.

Keempat, menjadikan thariqah dakwah Rasulullah SAW sebagai jalan dakwahnya. Gerakan dakwah harus mengacukan metode dakwahnya kepada metode dakwah Rasulullah SAW sebagai uswah hasanah kaum muslimin. Perjalanan dakwah Rasulullah SAW harus ditetapi dan diikuti sebagai wujud peneladanan kepada figur panutan umat sekaligus sebagai bukti ketundukan kepada Allah yang telah memerintahkan kaum muslimin untuk mengikuti Rasulullah SAW dalam segala tindak tanduknya. ${ }^{14}$

\section{Falsafah Gerakan Dakwah}

Falsafah kearifan gerakan dakwah merupakan dasar-dasar suatu gerakan yang ditegakkan di atas tiga rukun pokok, yaitu:

\section{Falsafah Rûhiyyah}

Falsafah ruhiyah merupakan falsafah yang paling penting dan sangat utama dalam mewujudkan pembinaan muslim, bahkan falsafah ruhiyah merupakan suatu kewajiban bagi setiap individu untuk senantiasa dekat dan mendekatkan diri kepada Allah SWT (muraqabat al-Allâh).

Muraqabat al-Allâh dapat juga dipahami melekatkan pengawasan dari Allah bagi segenap langkah dan segala bentuk aktivitas umat manusia, berkaitan dengan muraqabat al-Allâh ini, pengawasan Allah yang diyakini manusia dengan tujuan agar tumbuh keyakinan pada diri umat Islam bahwa Allah senantiasa melihat, mengawasi, mendengar terhadap semua pekerjaan (aktivitas) yang dilakukannya. ${ }^{15}$

\footnotetext{
${ }^{14} \mathrm{http}$ : //lists.topica.com/ lists/ artisnet/ read/ message. html? sorht\&mid = 170928694 diunduh jam 09.34 WIB tanggal 30 Nov 2011.

${ }^{15}$ Yusuf al-Qardawy, Auliyat al-Harakah al-Islamiyah fi al-Marhalah al-Qadimah, (Kairo: Maktabah Wahbah, 1991), terj, Ibnu Harun, Preoritas Gerakan Islam, (Jakarta: Usamah Press, 1992), hlm. 113.
} 
Berprinsip dari falsafah ruhiyah, muncul satu konsepsi tegas bahwa, bulatnya keyakinan manusia yang direfleksikan dalam sikap iman bahwa apa saja yang dilakukannya senantiasa diperhatikan oleh Allah, hal ini bermanfaat agar manusia benar-benar melaksanakan kewajiban dan kesetiaan penuh terhadap apa yang diperintahkan dan dilarang-Nya. Mengarahkan seluruh aktivitas untuk senantiasa bernuansa akhirat, dengan kekuatan imannya itu diharapkan pula umat Islam mampu menaklukkan gelombang materi sehingga mereka tidak tergelincir dengan sebab menjadikan materi sebagai satu-satunya sasaran dan tujuan akhir.

\section{Falsafah Iqtishâdiyyah}

Falsafah ekonomi bagi gerakan dakwah Islam dituntut untuk senantiasa berlandaskan pada syari'at Islam, oleh karena itu maka kegiatan ekonomi diarahkan kepada hal yang mengacu ke arah usaha memperoleh harta dan berproduksi dengan jalan yang benar serta mendistribusikannya pada jalan yang benar. Inti utama dalam falsafah ekonomi bagi gerakan dakwah Islam, yaitu menginginkan terwujudnya sistem kerja yang Islami. Islam mengatur perekonomian individu dan pemerintah, oleh karena itu suatu keharusan bagi umat Islam untuk giat bekerja, baik bidang pertanian, industri, perdagangan atau bidang-bidang lain yang sesuai dengan keahlian masing-masing, kendatipun demikian ada hal yang sangat mendasar yang harus diperhatikan oleh umat Islam sebagai kode etik dalam bekerja, bahwa pekerjaan yang dilakukan itu hendaknya sesuai dengan nilai-nilai syar'i yang memiliki moralitas tinggi. ${ }^{16}$

Berkaitan dengan falsafah iqtishâdiyyah ini, dapat disebutkan beberapa bentuk kajian pokok yang kerapkali diperbincangkan dalam kegiatan ekonomi Islam di dalamnya, masalah harta dan perniagaan. Masalah pertanian, masalah perindustrian, masalah peraturan perpajakan, masalah memerangi riba, masalah kesederhanaan dan masalah menyelesaikan kesulitan.

\footnotetext{
${ }^{16}$ Muhammad Faiz al-Math, Min Mu'jizat al-Islam (terj), Keistimewaan Islam, (Jakarta: Gema Insani Press, 1995), hlm. 106.
} 


\section{Falsafah Ijtimâ'iyyah}

Falsafah ijtimâ'iyyah dikenal dengan falsafah sosial kemasyarakatan, hal yang diprioritaskan dalam gerakan ini yaitu mengarah kepada seluruh lapisan masyarakat dengan tujuan tercapainya ishlâh ${ }^{17}$ (perbaikan), pembenahan lingkungan sosial di mana individu itu berkumpul dalam sebuah komunitas, mengikat mereka dengan suatu aturan hidup yang benar-benar islami.

Eksistensi masyarakat dalam pandangan Islam merupakan alat atau sarana untuk melaksanakan ajaran-ajaran Islam yang menyangkut kehidupan bersama, oleh karena itu masyarakat harus menjadi kerangka dasar kehidupan duniawi bagi terwujudnya kesatuan dan kerja sama menuju adanya suatu pertumbuhan manusia yang mewujudkan persamaan dan keadilan.

Pembinaan terhadap manusia haruslah dimulai dari pribadi-pribadi dengan cara memelihara diri, meningkatkan kualitas hidup dalam bingkai ibadah dan taqwa, dengan cara seperti ini, eksistensi masyarakat akan tampak lebih bernilai, oleh sebab itu konsekuensi falsafah ijtimâtiyyah yang harus diprioritaskan dan dijadikan inti pokok di lingkungan sosial manusia sekarang yaitu semata-mata ingin menjadikan sosok masyarakat Islam yang representatif, untuk memunculkan sosok masyarakat sebagaimana diharapkan, maka peran para aktivis dakwah hendaknya lebih gigih mengajak seluruh manusia untuk merealisasikan apa yang dicita-citakan, sehingga warga pun dapat merasakan kebahagiaan dan kedudukan yang layak.

Falsafah ijtimâizyyah memiliki sasaran (tujuan akhir) yakni terwujudnya sebuah masyarakat ideal, masyarakat yang selalu didamba-dambakan oleh umat manusia yang dalam al-Qur'an disinyalir dengan sebutan masyarakat

17 Adapun kaidah-kaidah perbaikan (ishlâh) yang islami yaitu gerakan yang bernuansa: (1) Rabbani: menghidupkan hati, mengangkat perasaan manusia ke derajat yang tinggi, serta menghubungkan umat manusia dengan Allah Yang Maha Kuasa, (2) Insaniyah (manusiawi), kaidah ini diangkat dari kerendahan-kerendahan cover nasionalisme, (3) Alamiyah (universal), dimana dijadikan bersaudara dalam hal kebenaran dan saling tolong menolong dalam hal kebaikan. Lihat Alwahidi Ilyas dalam Studi Gerakan Islam Masa Kini dalam Jakfar Puteh, Dakwah Tekstual dan Kontekstual (Peran dan Fungsi Pemberdayaan Ekonomi Umat, (Yogyakarta: AK Group, 2006), hlm. 13. 
mardhatillah atau baldatun thayyibatun wa rabbun ghafür. Tujuan lain falsafah ijtimâ'iyyah yang sangat utama, terwujudnya masyarakat yang berlandaskan aqidah, masyarakat yang senantiasa melaksanakan sebuah tanggung jawab atau kewajiban terhadap realisasi amar ma'rûf nahi munkar, sebab dengan jalan inilah keberadaan manusia yang disinyalir sebagai ahsani taqwim terpatri di tengah kehidupan masyarakat. Firman Allah dalam al-Qur'an surat Ali Imran ayat 110 yang artinya: "Kamu (wahai umat Muhammad) adalah sebaik-baik umat yang dilahirkan bagi umat manusia, (karena) kamu menyuruh berbuat yang baik dan melarang daripada perbuatan munkar, serta kamu menyuruh beriman kepada Allah dengan sebenar-benar iman."

\section{Profil ‘Aisyiyah Jawa Tengah}

'Aisyiyah Provinsi Jawa Tengah beralamat di Jalan Singosari No. 33 Semarang Kelurahan Pleburan Kota Semarang. Keberadaan kantor yang berlantai 3 ini sangatlah strategis, tepatnya di samping kampus Undip jalan Imam Subardjo atau pertigaan Rumah Sakit Muhammadiyah Roemani.

'Aisyiyah Provinsi Jawa Tengah masuk menjadi anggota Badan Koordinasi Organisasi Wanita (BKOW) pada tahun 1984. Posisi 'Aisyiyah Provinsi Jawa Tengah dalam Muhammadiyah merupakan organisasi otonom. Organisasi ini mempunyai misi menciptakan masyarakat utama yaitu masyarakat yang sehat sejahtera jasmani dan rohani.

Dalam menentukan arah gerakan organisasi agar cita-citanya dapat tercapai sesuai dengan harapan, 'Aisyiyah menentukan visi dan misi organisasi. Visi dan misi 'Aisyiyah Provinsi Jawa Tengah sebagaimana tertuang dalam buku "Informasi Organisasi" adalah sebagai berikut:

Visi 'Aisyiyah Provinsi Jawa Tengah, yaitu: (1) Islam membawa rahmat bagi segenap umat manusia (rahmatan lil âlamîn) sehingga tercipta masyarakat yang berbahagia, sejahtera dan berkeadilan, (2) masyarakat yang berbahagia, sejahtera dan berkeadilan merupakan masyarakat yang dibina oleh segenap warganya baik yang pria maupun yang wanitanya secara potensial (mempunyai kemampuan yang penuh) dalam masyarakat, (3) masyarakat utama dibentuk dengan menegakkan agama Islam secara istiqomah dan bersikap aktif melalui dakwah amar ma'rûfnahi munkar. 
Misi dari 'Aisyiyah Provinsi Jawa Tengah, adalah: (1) menegakkan dan menyebarluaskan ajaran Islam yang didasarkan kepada keyakinan tauhid yang murni menurut al-Qur'an dan Sunnah secara benar, (2) mewujudkan kehidupan Islami dalam diri pribadi keluarga dan masyarakat luas, (3) menggalakkan pemahaman terhadap landasan hidup keagamaan dengan menggunakan akal sehat yang dijiwai oleh ruh berfikir yang Islami dalam menjawab tuntutan dan menyelesaikan persoalan kehidupan dalam masyarakat luas, dan (4) menciptakan semangat beramal dengan ber-amar ma'rûf nahi munkar dan dengan menempatkan potensi segenap warga masyarakat, baik pria maupun wanita dalam mencapai tujuan organisasi. ${ }^{18}$

Para aktivis perempuan 'Aisyiyah memahami bahwa untuk mewujudkan visi dan misi ini tidaklah mudah, tetapi dibutuhkan kerja ekstra. Artinya, dalam perjuangannya haruslah mengerahkan seluruh potensi dan juga harus mempu menyatukan semua kekuatan yang ada yang dimiliki oleh organisasi melalui amal usaha yang selama ini dilakukan oleh 'Aisyiyah.

Tugas 'Aisyiyah Provinsi Jawa Tengah sama halnya dengan tugas organisasi yang ada di tingkat wilayah lainnya, yaitu menentukan kebijakan persyarikatan dan men-tafidz-kan keputusan Musyawarah Wilayah (Musywil), memimpin dan mengendalikan pelaksanaan berdasarkan AD/ ART (Anggaran Dasar dan Anggaran Rumah Tangga).

Pimpinan wilayah 'Aisyiyah atas nama persyarikatan dapat melaksanakan tindakan di dalam dan di luar pengadilan. Secara rinci tugas dan fungsinya sebagai berikut: (1) men-tanfidz-kan keputusan Musywil, (2) menetapkan kebijakan persyarikatan berdasarkan keputusan Musywil, (3) menetapkan kegiatan berdasarkan program yang telah diputuskan di Musywil, (4) memimpin pelaksanaan kegiatan berdasarkan keputusan Musywil, (5) melaksanakan pengawasan dan pengendalian kegiatan, dan (6) mewakili persyarikatan di dalam dan di luar pengadilan. ${ }^{19}$ hlm. 5-6.

18 'Aisyiyah, Informasi Organisasi 'Aisyiyah Wilayah Jawa Tengah, (Semarang: t.p, 2005),

${ }^{19}$ Tahfidz, Keputusan Rapat Kerja ke 1 Pimpinan Wilayah 'Aisyiyah Jawa Tengah, (Semarang: tp, 2006), hlm. 6. 


\section{E. Gerakan Dakwah Aktivis Perempuan 'Aisyiyah Jawa Tengah}

Kegiatan-kegiatan dakwah yang diagendakan oleh 'Aisyiyah Provinsi Jawa Tengah dapat dilihat dari masing-masing pendekatan dakwah dalam beberapa bidang. Bidang-bidang yang diprioritaskan oleh 'Aisyiyah Jawa Tengah antara lain bidang pendidikan, kesehatan, sosial dan ekonomi. Gerakan dakwah yang telah berhasil direalisasikan oleh para aktivis perempuan 'Aisyiyah Jawa Tengan antara lain: bidang tabligh dan kehidupan Islami serta bidang kesejahteraan sosial.

\section{Bidang Tabligh dan Kehidupan Islami}

Di dalam bidang tabligh dan kehidupan islami, 'Aisyiyah mempunyai beberapa program, antara lain: (1) menginstruksikan dan mengefektifkan pembinaan akhlak dan ibadah, (2) dakwah multimedia, (3) membentuk dan mengembangkan laboratorium dakwah sebagai pusat pengembangan dan pembinaan, (4) meningkatkan fungsi masjid dan mushalla sebagai sarana penyiaran terprogram, (5) mengembangkan lembaga pendidikan 'Aisyiyah sebagai wahana dakwah, (6) mengimplementasikan dakwah kultural, (6) mengintensifkan dakwah jamaah, (7) pemanfaatan objek wisata dengan dakwah religius, (8) menyiapkan ulama tarjih perempuan.

Menginstruksikan dan mengefektifkan pembinaan akhlak dan ibadah mempunyai beberapa sasaran, antara lain: memasyarakatkan adabul mar'ah fil Islam, membudayakan tadarus al-Qur'an dan shalat berjamaah, membudayakan perawatan jenazah dan bimbingan ta'ziyah, mendirikan biro konsultasi akibat narkotika dan penyakit masyarakat, mendirikan biro konsultasi tentang keluarga sakinah, memasyarakatkan usaha pencegahan sejak dini terhadap bahaya miras, NAPZA, demoralisasi, seks bebas, kriminalitas, dan lain-lain melalui pembinaan keluarga secara langsung, penyebaran liflet, booket dan publikasi media cetak dan organisasi, memberikan informasi tentang pentingnya pendampingan orang tua terhadap anak dalam beradaptasi dengan dunia media dan informasi.

Program dakwah multimedia dilakukan dengan beberapa sasaran, antara lain: menerbitkan buletin dakwah (brosur) secara berkala, meng- 
adakan kerjasama penyuluhan melalui televisi dan RRI, menghidupkan pengajian anggota atau ranting, memiliki home page di internet.

Program dakwah bidang pembentukan dan pengembangan laboratorium dakwah sebagai pusat pengembangan dan pembinaan dilakukan dengan beberapa sasaran, antara lain: menyiapkan kantor dan perlengkapan, membuat peta dakwah wilayah Jawa Tengah, membuat chard data mubalighat dan membentuk chard mubalighot, mengadakan TOT (Training of Trainer) mubalighat, mengadakan penelitian dakwah dan memahami fenomena masyarakat, mendirikan biro konsultasi dakwah.

Meningkatkan fungsi masjid dan mushalla sebagai sarana penyiaran terprogram dilakukan dengan beberapa sasaran, antara lain: mengikutsertakan atau memberdayakan 'Aisyiyah dalam kepengurusan masjid dan mushalla pada bagian wanita, membentuk kelompok majlis taklim wanita di masjid dan mushalla, meningkatkan kegiatan ubudiyah dan sosial masyarakat masjid dan mushalla.

Mengembangkan lembaga pendidikan 'Aisyiyah sebagai wahana dakwah dilakukan dengan beberapa sasaran, antara lain: pendidikan formal dengan melakukan penigkatan kualitas lembaga pendidikan yang dimiliki 'Aisyiyah, dan pendidikan nonformal dengan membentuk majlis taklim di sekolah-sekolah 'Aisyiyah.

Mengimplementasikan dakwah kultural dilakukan dengan beberapa sasaran, antara lain: membuat panduan (tuntutan praktis) dakwah kultural yang sejalan dengan 'Aisyiyah dan Muhammadiyah, mencegah terjaadinya praktek-praktek keagamaan yang tidak sejalan dengan 'Aisyiyah dan Muhammadiyah, menghidupkan kembali gerakan dakwah jamaah secara kontinu.

Pemanfaatan objek wisata dengan dakwah religius dilakukan dengan beberapa sasaran, antara lain: membentuk pemandu wisata religius, membuat tuntutan praktis wisata religius, ikut serta berpartisipasi menyiapkan fasilitas ibadah di tempat wisata, menghidupkan safari dakwah 'Aisyiyah.

Menyiapkan ulama tarjih perempuan dilakukan dengan beberapa sasaran, antara lain: mengikutsertakan dalam pendidikan ulama tarjih yang 
dimiliki Muhammadiyah seperti pondok Sobron Solo atau pendidikan Ulama Tarjih di Yogyakarta.

\section{Bidang Kesejahteraan Sosial}

Di dalam bidang kesejahteraan sosial, 'Aisyiyah Jawa Tengah mempunyai beberapa program, antara lain: (1) meningkatkan kepedulian dan usaha-usaha pelayanan dan penyantunan bagi kelompok masyarakat dhu'afa atau miskin, (2) pemberdayaan lembaga-lembaga sosial (panti asuhan, panti jompo, balai latihan, rumah singgah) dengan menggunakan pendekatan yang sesuai dengan kondisi dan profesional, (3) peningkatan kesejahteraan masyarakat miskin di perkotaan dan pedesaan dengan menggunakan berbagai pendekatan, (4) meningkatkan pola pengasuhan anak di dalam panti dengan pola pendidikan pesantren dan pola persemaian kader 'Aisyiyah, (5) meningkatkan kepekaan, pelayanan dan pengelolaan terhadap penanggulangan bencana atau musibah yang terjadi di masyarakat baik yang bersifat lokal maupun nasional, (6) mengupayakan advokasi publik yang menyangkut kebijakan masalah-masalah sosial di berbagai lapisan kepentingan masyarakat agar terdapat rasa keadilan, (7) peningkatan peran keluarga sebagai basis pembinaan moral bangsa, (8) mengembangkan pemberian bantuan terhadap para korban traficking antara lain dengan membentuk women crisis centre di daerahdaerah strategis dan membuat buku panduan.

Meningkatkan kepedulian dan usaha-usaha pelayanan dan penyantunan bagi kelompok masyarakat dhu'afa atau miskin dilakukan dengan dua sasaran, antara lain: tanggap dan peduli terhadap masyarakat dhu'afa atau miskin di lingkungana sekitar dengan cara mendata dan menindaklanjuti, mencari dana untuk mencukupi kebutuhan panti atau anak asuh.

Pemberdayaan lembaga-lembaga sosial yang dikelola 'Aisyiyah (panti asuhan, panti jompo, balai latihan, rumah singgah) dengan menggunakan pendekatan yang sesuai dengan kondisi dan profesional dilakukan dengan beberapa sasaran, antara lain: melengkapi fasilitas untuk kegiatan, misalnya komputer, alat-alat dan bahan kerajinan, mesin jahit dan alat pembuat kue, mencari tenaga yang profesional yang dapat melatih dan membina kegiatan, dibentuk usaha pertokoan, koperasi di lingkungan panti. 
Peningkatan kesejahteraan masyarakat miskin di perkotaan dan pedesaan dengan menggunakan berbegai pendekatan dilakukan dengan beberapa sasaran, antara lain: mengadakan kursus keterampilan, memberikan pinjaman modal usaha tanpa bunga, mengadakan penyuluhan dan pembinaan melalui pengajian atau kegiatan lainnya (PKK).

Meningkatkan pola pengasuhan anak di dalam panti dengan pola pendidikan pesantren dan pola persemaian kader 'Aisyiyah dilakukan dengan beberapa sasaran, antara lain: pendalaman pendidikan agama, pendalaman al-Qur'an, pendalaman perjuangan Muhammadiyah dan 'Aisyiyah.

Meningkatkan kepekaan, pelayanan dan pengelolaan terhadap penanggulangan bencana atau musibah yang terjadi di masyarakat baik yang bersifat lokal maupun nasional dilakukan dengan beberapa sasaran, antara lain: menampung anak korban bencana yang ditinggal orang tuanya, memberikan bantuan moril maupun spiritual bekerja sama dengan bagian lainnya dan pemerintah.

Mengupayakan advokasi publik yang menyangkut kebijakan masalahmasalah sosial di berbagai lapisan kepentingan masyarakat agar mendapat rasa keadilan dilakukan dengan beberapa sasaran antara lain: mendampingi masyarakat yang tertindas untuk mendapat keadilan, memberikan penyuluhan kepada masyarakat agar berani mempertahankan atau memperjuangkan haknya.

Meningkatkan peran keluarga sebagai basis pembinaan moral bangsa dilakukan dengan beberapa sasaran, antara lain: memberikan penyuluhan dan pembinaan kepada masyarakat pentingnya pendidikan agama sedini mungkin, juga sopan santun di keluarga melalui pengajian dan kegiatan lainnya, memberikan himbauan kepada masyarakat pentingnya pendidikan sampai jenjang yang lebih tinggi bagi anak-anaknya, memberikan penyuluhan dan pembinaan kepada masyarakat untuk menjaga lingkungan sekitarnya sebagai lingkungan yang damai, tenang, aman menghindari terjadinya lingkungan anarkis, amoral, minuman keras, judi dan obat-obat terlarang.

Mengembangkan pola pemberian bantuan terhadap para korban traficking antara lain dengan membentuk women crisis centre di daerah-daerah yang strategis dan membuat buku panduan dilakukan dengan beberapa sasar- 
an, antara lain: mendampingi para korban traficking, memberikan penyuluhan kepada remaja agar tidak tergiur dengan rayuan calo pekerja, mengadakan kursus untuk remaja di bidang komputer, menjahit, masak dan lain-lain. ${ }^{20}$

\section{F. Kesimpulan}

Gerakan dakwah diartikan setiap aktivitas dalam rangka melaksanakan dakwah Islam untuk mengajak manusia kepada kebaikan, menyuruh kepada yang ma'ruf dan mencegah dari yang munkar, adapun secara khusus, gerakan dakwah sering disebut sebagai gerakan Islam (al-harakah alislâmiyyah) atau juga disebut jamaah dakwah atau juga disebut kutlah dakwah (kelompok dakwah), yaitu sebuah kelompok yang terdiri dari orang-orang yang bersama-sama melaksanakan dakwah dalam satu kesatuan kerja dan koordinasi.

Gerakan dakwah para aktivis perempuan 'Aisyiyah Jawa Tengah sudah dilakukan dengan penggerakan organisasi yang ideal, hal ini dapat dilihat dari berbagai koordinasi dan kerja sama antar lembaga dalam organisasi. Solidnya kerjasama yang dilakukan menjadikan 'Aisyiyah dapat mengaplikasikan kegiatan dakwahnya di masyarakat. Kegiatan dakwah yang dilakukannya secara langsung dapat berdampak positif bagi anggota dan masyarakat luas dari berbagai bidang kehidupan.]

\section{Daftar Pustaka}

'Aisyiyah, Informasi Organisasi 'Aisyiyah Wilayah Jawa Tengah, Semarang: t.p, 2005. Alwahidi Ilyas dalam Studi Gerakan Islam Masa Kini dalam Jakfar Puteh, Dakwah

Tekstual dan Kontekstual (Peran dan Fungsi Pemberdayaan Ekonomi Umat), Yogyakarta, AK Group, 2006.

Arifin, Psikologi Dakwah: Suatu Pengantar Studi, Jakarta: Bumi Aksara, 1993.

Departemen Pendidikan Nasional, Kamus Besar Bahasa Indonesia, Jakarta: Balai Pustaka, 2005.

20 Tahfidz, Keputusan Rapat Kerja ke-1 Pimpinan Wilayah 'Aisyiyah Jawa Tengah, (Semarang: tp, 2006), hlm. 24-29. 
Fahmi, Abu, Pergilah ke Jalan Islam: Sebuah Paket Gerakan Dakwah Masa Kini, Jakarta: Gema Insani Press, 1991.

Faizah dan Efendi, Muchsin, Psikologi Dakwah, Jakarta: Kencana, 2006.

Halimi, Safrodin, Etika Dakwah dalam Perspektif al-Qur'an: Antara Idealitas Qur'ani dan Realitas Sosial, Semarang: Walisongo Press, 2008.

Kayo, Pahlawan, Khatib, Manajemen Dakwah dari Dakwah Konvensional menuju Dakwah Profesional, Jakarta: Amzah, 2007.

Muhammad Faiz al-Math, Min Mu'jizat al-Islam (terj), Keistimewaan Islam, Jakarta: Gema Insani Press, 1995

Rokhmat, Abu, Ideologi dan Gerakan Dakwah Salafi Wahabi: Studi Kasus di Kota Semarang, Semarang: Puslit IAIN Walisongo, 2010.

Shadiq Amin, Mencari Format Gerakan Dakwah Ideal, Jakarta: Al-I'tishom Cahaya Umat, 2010.

Tahfidz, Keputusan Rapat Kerja ke-1 Pimpinan Wilayah 'Aisyiyah Jawa Tengah, Semarang: tp, 2006.

Tantowi, Pramono U, Muhammadiyah "Digugat" Reposisi di Tengah Indonesia yang Berubah, Jakarta: Kompas Media Nusantara, 2000.

Wafiyah dan Pimay, Sejarah Dakwah, Semarang: Rasail, 2005.

Yusuf al-Qardawy, Auliyat al-Harakah al-Islamiyah fi al-Marhalah al-Qadimah, Kairo: Maktabah Wahbah, 1991, terj, Ibnu Harun, Preoritas Gerakan Islam, Jakarta: Usamah Press, 1992.

http://lists.topica.com/lists/artisnet/read/message.html?sorht\&mid=1709 28694 diunduh jam 09.34 WIB tanggal 30 Nov 2011. 
